\title{
THE EFFECTS OF FEDERAL REGULATION ON CHEMICAL INDUSTRY INNOVATION
}

\author{
J. Clarence Davies*
}

\section{INTRODUCTION}

The extent to which federal laws and regulations, particularly the Toxic Substances Control Act (TSCA), ${ }^{1}$ have adversely affected the development of new chemical products, has become a matter of considerable interest and controversy. The question is both important and complex.

The importance of the question has at least two dimensions. First, the question is important because of its implications on how environmental health laws are administered. If it becomes generally accepted that these laws significantly impinge on innovation, it is then likely that the implementing regulations, and perhaps even the laws themselves, will be modified so as to impose less of a burden on industry. Modifications of TSCA regulations for reviewing new chemicals have already been proposed. ${ }^{2}$

The second reason the regulation-innovation question is important is that it highlights in a dramatic way the need to consider the interaction and relationship between private sector economic processes and governmental regulation. In the health and safety area, the interaction between the two major institutions of society, government and industry, has been largely neglected except for rhetorical purposes. Society is beginning to realize that the true effects of regulations cannot be understood without understanding how the regulations relate to the decisionmaking process, the flow of money, and other characteristics of the private sector.

The relationship between regulation and innovation is quite complex. It has been examined in detail only in the context of new drugs, ${ }^{3}$ an area that will not be covered in this article. The complexity derives from the many different regulations, the diversity of the chemical industry, and the differences among types of innovation. Each of these factors will be discussed briefly.

Copyright $(1983$ by Law and Contemporary Problems

* Executive Vice-President, The Conservation Foundation.

1. 15 U.S.C. $\S 2601$ (1982).

2. The most important proposed modifications would exempt more than half of the new chemcials now covered by TSCA from having to submit a premanufacturing notification. See Draft of EPA Proposed Exemption for Site-Limiled Chemical Intermediales and New Chemicals Manufactured in Quantities of 10,000 Killograms or Less, 6 Chem. Reg. ReP., (BNA) No. 8 (May 21, 1982).

3. See, e.g., Impact of Public Policy on Drug Innovation and Pricing (S. Mitchell \& E. Links eds. 1976); Regulating New Drugs (R. Landau ed. 1973); D. Schwartzman, Innovation in the Pharmaceutical Industry (1976). 


\section{A. Types of Regulations}

There are a large number of health and safety statutes that have an impact on the chemical industry. For the purpose of considering their impact on innovation, three general types of regulatory schemes should be distinguished. These schemes should be labeled as follows: environment-oriented, product registration, and product oversight.

Environment-oriented statutes are the most common, and they are focused on the level of contamination of some aspect of the environment. Included in this category are the Clean Air Act, ${ }^{4}$ the Clean Water Act, ${ }^{5}$ the Occupational Safety and Health Act, ${ }^{6}$ the Safe Drinking Water Act, ${ }^{7}$ the Resource Conservation and Recovery Act ${ }^{8}$ and the Comprehensive Environmental Response, Compensation and Liability Act. ${ }^{9}$

Product registration statutes require that particular kinds of products be approved by the government before they can be manufactured or marketed. The Federal Food, Drug, and Cosmetic Act ${ }^{10}$ and the Federal Insecticide, Fungicide, and Rodenticide Act (FIFRA) ${ }^{11}$ are the only two health and safety statutes in this category.

Product oversight statutes focus on particular products but do not require government approval for new products. The Hazardous Substances Act, ${ }^{12}$ the Consumer Product Safety Act, ${ }^{13}$ the Flammable Fabrics Act, ${ }^{14}$ and the Toxic Substances Control Act ${ }^{15}$ are examples.

Liability laws, which are primarily state laws, constitute still another category. Since liability laws were canvassed in a recent Congressional report, no further mention will be made of them. ${ }^{16}$

The reason for making these distinctions is that the different types of regulatory schemes may have quite different effects on innovation. ${ }^{17}$ Some of these differences will be described later.

\section{B. Diversity of the Chemical Industry}

The chemical industry produces a vast array of products which are used by all other industries in the economy. The TSCA inventory of chemicals in commerce

\footnotetext{
4. 42 U.S.C. $\S 1857$ (1976).

5. 33 U.S.C. $\$ 1251$ (Supp. V 1981).

6. 29 U.S.C. $\$ 651(1976)$.

7. 42 U.S.C. $\$ 300(f)(1976)$.

8. 42 U.S.C. $\$ 6901$ (1976).

9. 42 U.S.C. $\$ 9601$ (1976).

10. 21 U.S.C. $\S 301$ (1976).

11. 7 U.S.C. $\$ 136$ (1982).

12. 15 U.S.C. $\$ \S 1261-1274$ (1982).

13. 15 U.S.C. $\$ 2051$ (1982).

14. 15 U.S.C. $\$ 1193$ (1982).

15. 15 U.S.C. $\$ 2601$ (1982).

16. See Staff of Senate Comm. on Environment and Public Works, 97th Cong., 2d Sess., Report ON INJURies and Damages from Hazardous Wastes-ANalysis and IMPROVEMENT OF Legal Remedies (Comm. Print 1982).

17. See Stewart, Regulation, Innovation, and Administrative Law: A Conceptual Framework, 69 CALIF. L. REV. 1259 (1981).
} 
lists more than 55,000 chemicals, and this inventory excludes thousands of drugs, pesticides, food additives, and cosmetics. ${ }^{18}$ Some chemical products are used only to make other chemicals. Others are sold to processors who incorporate them into consumer goods. Many major chemical companies, such as Dow and DuPont, sell some of their products directly to the buying public.

The Standard Industrial Classification Manual contains eight major divisions of chemicals and allied products: industrial inorganic chemicals; plastics, synthetic rubber, and man-made fibers; drugs; soaps, detergents, and cosmetics; paints, varnishes, and allied products; agricultural chemicals; industrial organic chemicals, and miscellaneous chemical products. ${ }^{19}$ Some chemical companies only produce one product or one type of product. Many companies produce products in several or all of the major industry divisions. Many companies that make chemicals are not primarily chemical companies. Four of the top ten chemical producers in 1981 (Exxon, Shell Oil, Gulf Oil, and Occidental Petroleum) were oil companies. ${ }^{20}$ Another two of the top ten had only about half their total sales attributable to chemicals (Union Carbide, 57\%; W.R. Grace, 45\%). ${ }^{21}$ The top twenty-five included a photographic equipment company (Eastman Kodak), a dairy products company (Borden), and U.S. Steel. ${ }^{22}$

A total of 11,500 companies are estimated to be involved in producing and processing chemicals. ${ }^{23}$ About 1,000 companies are in the basic chemical industry and 3,100 in allied products with the remaining 7,400 in chemical processing. ${ }^{24}$ In 1980 , thirty-six companies had chemical sales of over $\$ 1$ billion. ${ }^{25}$ But there are thousands of chemical companies with annual sales of less than $\$ 1$ million. In 1981, DuPont spent $\$ 575$ million on research and development, and Dow spent $\$ 404$ million. ${ }^{26}$ But thousands of companies do no research and development. Some companies depend on innovation for their continued existence. Many do not innovate at all. In short, the industry is so large and diverse that it is almost impossible to subject it to valid generalizations.

\section{Varieties of Innovation}

Most broadly, innovation can be described as the creation and introduction of something new. Technological innovation has been defined as "a conscious attempt to bring about, through technology, a change in the way man lives." 27 It

18. Office of Toxic Substances, U.S. Environmental Protection Agency, Toxic Substances Control Act (TSCA) Chemical Substance Inventory (1979 \& Cum. Supp. June 1980).

19. Office of Management and Budget, Standard Industrial Classification Manual 111 (1972).

20. Facts and Figures for the Chemical Industry, Chemical \& ENG'G News, June 8, 1981, at 31, 44.

21. Id.

22. Id.

23. Foster D. Snell, Inc., Study of the Potential Economic Impacts of the Proposed Toxic Substances Control Act as Illustrated by Senate Bill S. 776, at 22 (1975).

24. Id.

25. Id.

26. Facts and Figures for Chemical Research $\mathcal{E}^{\circ}$ Development, CHemical \& EnG'c News, July 26, 1982, at 38,64 .

27. Drucker, Technological Trends in the Twentieth Century, in TECHNOLOGICAL INNOvatION: A CRITICAL Review of CURRENT KNOWLEDGe 10 (1975). 
is the process by which technological knowledge is developed and transformed into specific products, processes, and services to meet human needs.

This article defines innovation to include the sequence of steps in the conception, development, testing, production, adoption, and diffusion of a technology. The focus, however, will be on the stages between invention and widespread diffusion because these are the stages most likely to be affected by regulation.

Distinctions must be made among the kinds of innovations as well as among the stages in the innovation process. Most important is the distinction between product and process innovations. Much of the innovation in the chemical industry is changed processes, that is, improved methods for making the same product. This article, however, will concentrate on the innovation of new products because this topic has been the subject of primary concern with respect to the chemical industry.

Given the different types of regulatory schemes, the diversity of the chemical industry, and the varieties of innovation, it should not be hard to understand why the interrelationship of the three is very complex. Throughout the rest of this article the reader should keep in mind that there are likely to be exceptions to almost every statement that is made.

\section{ADVERSE EFFECTS OF REGULATION ON INNOVATION}

To understand how regulation affects innovation in the chemical industry it is first necessary to understand the dynamics of the innovation process in the industry. This is difficult, however, not only because of the complexities discussed above, but also because there have been very few empirical examinations of the innovation process in the chemical industry. To understand chemical innovation, three interrelated levels or models must be considered: the industry level, the company level, and the product level.

\section{A. Industry-Level Effects: Market Concentration}

Government regulation may have the effect of increasing concentration in an industry by increasing the cost of developing and marketing products and thereby eliminating all but large firms from the market. This effect, if it occurs, will probably influence the rate and type of innovation that takes place in the industry, although the existing literature contains contradictory findings on the relationship between innovation, on the one hand, and industry concentration and the size of a firm, on the other. ${ }^{28}$

Tables 1 and 2 present data on concentration in the chemical industry. Other measures could be used, but by almost any measure there has not been any significant trend toward increasing concentration in the industry.

28. 2 C.T. Hill, A State of the Art Review of the Effects of Regulation on Technological Innovation in the Chemical and Allied Products Industries — "CAPI Project" 80-83 (1975). 
TABLE 1

Share of Value of Shipments Accounted for by The Eight Largest Companies in Segments of the Chemical INDUSTRY, 1977 AND EARLIER YEARS*

\begin{tabular}{|c|c|c|c|c|c|c|}
\hline \multirow[b]{2}{*}{$\underline{\text { SIC Code }}$} & \multirow[b]{2}{*}{ Industry } & \multicolumn{5}{|c|}{ Percentage Share } \\
\hline & & $\underline{1947}$ & $\underline{1958}$ & 1967 & $\underline{1972}$ & 1977 \\
\hline 2812 & Alkalies \& Chlorine & 93 & 89 & 88 & 91 & 87 \\
\hline 2813 & Industrial Gases & 88 & 88 & 84 & 81 & 84 \\
\hline 2816 & Inorganic Pigments & NA & 83 & 78 & 72 & 78 \\
\hline 2819 & Industrial Inorganic Chemicals, nec** & NA & NA & NA & 52 & 49 \\
\hline 2821 & Plastic Materials \& Resins & NA & NA & NA & 41 & 37 \\
\hline 2822 & Synthetic Rubber & 100 & 86 & 82 & 81 & 83 \\
\hline 2823 & Cellulosic Manmade Fibers & NA & NA & 99 & NA & 100 \\
\hline 2824 & Organic Fibers, Noncellulosic & NA & NA & 94 & 91 & 90 \\
\hline 2833 & Medicinals \& Botanicals & NA & 77 & 81 & 75 & 78 \\
\hline 2834 & Pharmaceutical Preparations & 44 & 45 & 40 & 44 & 43 \\
\hline 2841 & Soap \& Other Detergents & NA & NA & 78 & 74 & 71 \\
\hline 2842 & Polishes \& Sanitation Goods & NA & NA & NA & 54 & 56 \\
\hline 2844 & Toilet Preparations & 38 & 45 & 52 & 53 & 56 \\
\hline 2851 & Paints \& Allied Products & NA & NA & 35 & 34 & 36 \\
\hline 2865 & Cyclic Crudes \& Intermediates & NA & NA & 64 & 52 & 60 \\
\hline 2869 & Industrial Organic Chemicals, nec & NA & 70 & 58 & 57 & 55 \\
\hline 2873 & Nitrogenous Fertilizers & NA & NA & NA & 53 & 54 \\
\hline 2874 & Phosphatic Fertilizers & NA & NA & NA & 47 & 57 \\
\hline 2875 & Fertilizers, mixing only & 28 & 28 & 36 & 38 & 37 \\
\hline 2979 & Agricultural Chemicals, nec & NA & NA & NA & 57 & 64 \\
\hline 2891 & Adhesives \& Sealants & NA & NA & NA & 31 & 35 \\
\hline 2899 & Chemical Preparations, nec & NA & NA & 28 & 26 & 25 \\
\hline \multicolumn{7}{|c|}{$\begin{array}{l}\text { * Excludes industry segments with } 1977 \text { value of shipments of less than } \$ 1 \text { billion. } \\
\text { ** "nec" means not elsewhere classified. }\end{array}$} \\
\hline urce: $\begin{array}{l}\text { BUF } \\
\text { CEN }\end{array}$ & $\begin{array}{l}\text { a of the Census, U.S. Dep't of Coms } \\
\text { ation Ratios in Manufacturing, at } 9\end{array}$ & ת & ov & 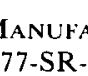 & $U$ & ON- \\
\hline
\end{tabular}

Tables 1 and 2 may underestimate the degree of concentration in certain segments of the industry. For example, most pesticide manufacturers would be included in Standard Industrial Code (SIC) 2879. It is generally agreed that there are no small companies that manufacture pesticide ingredients, but the many small companies that mix ingredients together (known as formulators) are included in the same category and thus reduce the concentration ratio.

Even in the pesticides industry, however, there has not been any detectable trend toward concentration. For insecticides (SIC 28795), the eight-, twenty-, and fifty-company concentration percentages were unchanged between 1972 and 1977. For herbicides (SIC 28796), the eight-company concentration percentage declined from eighty-nine to eighty-four percent between 1972 and 1977, and the twentyand fifty-company percentages were unchanged. No data for years earlier than 1972 are available, and for fungicides (SIC 28797 and 28798) only 1977 data are available. There was an increase in concentration for household pesticidal preparations (SIC 28799), but this is a comparatively small portion of the pesticide market. An examination of companies entering and exiting the pesticide 
TABLE 2

Share of Value of Shipments Accounted for by the Fifty

LaRgest Companies in Segments of THE CHEMICAL INDUSTRY, 1977 AND EARLIER YEARS*

\begin{tabular}{|c|c|}
\hline SIC Code & Industry \\
\hline 2812 & Alkalies \& Chlorine \\
\hline 2813 & Industrial Gases \\
\hline 2816 & Inorganic Pigments \\
\hline 2819 & Industrial Inorganic Chemicals, nec* \\
\hline 2821 & Plastic Materials \& Resins \\
\hline 2822 & Synthetic Rubber \\
\hline 2823 & Cellulosic Manmade Fibers \\
\hline 2824 & Organic Fibers, Noncellulosic \\
\hline 2833 & Medicinals \& Botanicals \\
\hline 2834 & Pharmaceutical Preparations \\
\hline 2841 & Soap \& Other Detergents \\
\hline 2842 & Polishes \& Sanitation Goods \\
\hline 2844 & Toilet Preparations \\
\hline 2851 & Paints \& Allied Products \\
\hline 2865 & Cyclic Crudes \& Intermediates \\
\hline 2869 & Industrial Organic Chemicals, nec \\
\hline 2873 & Nitrogenous Fertilizers \\
\hline 2874 & Phosphatic Fertilizers \\
\hline 2875 & Fertilizers, mixing only \\
\hline 2979 & Agricultural Chemicals, nec \\
\hline 2891 & Adhesives \& Sealants \\
\hline 2899 & Chemical Preparations, nec \\
\hline
\end{tabular}

\begin{tabular}{|c|c|c|c|}
\hline \multicolumn{4}{|c|}{ Percentage Share } \\
\hline 1958 & 1967 & 1972 & 197 \\
\hline NA & NA & 100 & 100 \\
\hline 98 & 99 & 98 & \\
\hline 99 & 99 & 99 & \\
\hline NA & NA & 93 & \\
\hline NA & NA & 90 & 8 \\
\hline NA & NA & 100 & 10 \\
\hline NA & NA & NA & $\mathrm{N} A$ \\
\hline NA & 100 & 100 & 10 \\
\hline 98 & 98 & 98 & 9 \\
\hline 87 & 90 & 91 & 9 \\
\hline NA & 92 & 92 & 8 \\
\hline NA & NA & 78 & 7 \\
\hline 87 & 90 & 91 & 9 \\
\hline NA & 61 & 66 & 6 \\
\hline NA & 97 & 96 & 9 \\
\hline 96 & 92 & 92 & 9 \\
\hline NA & NA & 100 & 9 \\
\hline NA & NA & 99 & 10 \\
\hline 64 & 72 & 74 & 7 \\
\hline NA & NA & 89 & 8 \\
\hline NA & NA & 76 & 7 \\
\hline NA & 62 & 58 & 5 \\
\hline
\end{tabular}

* Excludes industry segments with 1977 value of shipments of less than \$1 billion. Data for 1947 are not available for the fifty largest companies.

** "nec" means not elsewhere classified.

Source: Bureau of The Census, U.S. Dep't of Commerce, 1977 Census of Manufactures, Concentration Ratios in Manufacturing, at 9-30-33 (Subject Series MC77-SR-9).

manufacuring industry between 1972 and 1977 found that ten companies started manufacturing basic pesticide ingredients for the first time in the period between 1972 and 1977 while thirteen companies stopped manufacturing pesticides. ${ }^{29}$ Three of the companies that stopped produced only very small amounts of one chemical. ${ }^{30}$

The above data are not intended to imply that small companies are not precluded from manufacturing pesticides. In fact, they are. But the barriers to entering the market are the large capital investment required for manufacturing facilities, the large cash reserves necessary either to purchase patent licenses or to sort through a large number of chemicals looking for a suitable pesticide, and the network of salesmen to distribute the product. Regulatory requirements are also a barrier to entering the market, but if all of the regulatory requirements disappeared, it would still be impossible for a small firm to get into the pesticide manu-

29. Conservation Foundation, Product Regulation and Chemical Innovation IV-14 (1980) (report to the Office of Technology Assessment, U.S. Congress) [hereinafter cited as CF-OTA Study].

30. Id. 
facturing business. The concentration data cited above indicate that increases in regulatory requirements during the 1970's have not had a significant concentrating effect.

Research and development is probably more concentrated than sales or production in the chemical industry. Over $60 \%$ of the research and development funds for industrial chemicals are spent by four companies. DuPont alone accounts for about one-fourth of all research and development in the chemical industry. ${ }^{31}$ Seventy-one percent of the new chemical notifications under TSCA were submitted by companies with sales over $\$ 500$ million. Only $2 \%$ of the notifications were submitted by companies with sales under $\$ 10$ million. ${ }^{32}$ This would suggest that small companies do little new chemical innovation. One, therefore, need not worry too much about regulation impeding innovation in small companies. However, some industry representatives have interpreted the TSCA figures to indicate that regulation has already put an end to small companies developing new chemicals, and that in the good old days, perhaps before 1976, many small companies developed many new chemicals.

\section{B. Company-Level Effects: Research and Development}

There are two types of innovation-related decisions that are applicable to an entire company, not just to an individual product. The first is the philosophy or strategy that the firm wants to pursue with respect to innovation. The second is the annual decision of how much to invest in research and development.

The specific decisions within a firm regarding innovation are governed, implicitly or explicitly, by the corporate strategy of innovation. Such strategies are of great importance, but they are also elusive because they can take a variety of forms, and only rarely are they explicitly documented.

The most basic strategy choice, in the realm of innovation, is whether a firm wants to engage in innovative product activity at all. All firms within some industries, and many firms within innovative industries such as the chemical industry, choose to compete for market share by marketing at a lower price rather than by developing new products. ${ }^{33}$ Sometimes the pricing strategy itself depends on making process innovations that permit more efficient production. Another strategy choice may involve the choice of product lines where research emphasis will be placed. Still another choice is between conducting research in-house or buying patent rights from other, sometimes foreign, firms.

One effect of health and safety regulations may be to place more emphasis on minor improvements in existing products than on more radical innovations. Because existing products have been on the market their health and environmental effects are presumed by some to be better known than those of a com14.

31. Falwell, RGDD Support Starts 1980's with Strong Year, ChEmiCal \& ENG'G News, Jan. 21, 1980, 12,

32. Address by Douglas G. Bannerman, Impact of TSCA on Market Introduction of New Chemicals, American Chemical Society in Las Vegas, Nev., slide 8 (Mar. 31, 1982).

33. E. Mansfield, J. Rapaport, J. Schnee, S. Wagner \& M. Hamburger, Research \& InnovaTION IN THE MODERN CORPORATION 4-5 (1971) [hereinafter cited as MANSFIELD]. 
[Vol. 46: No. 3

pletely new compound. Also, government regulators are likely to give more careful scrutiny to major new products than to minor improvements. The time delay involved in government regulation may also discourage radical innovations.

The data on new pesticide chemicals (Figure 1) and on new pharmaceutical chemicals (Figure 2) lend some limited support to this thesis. There has been a

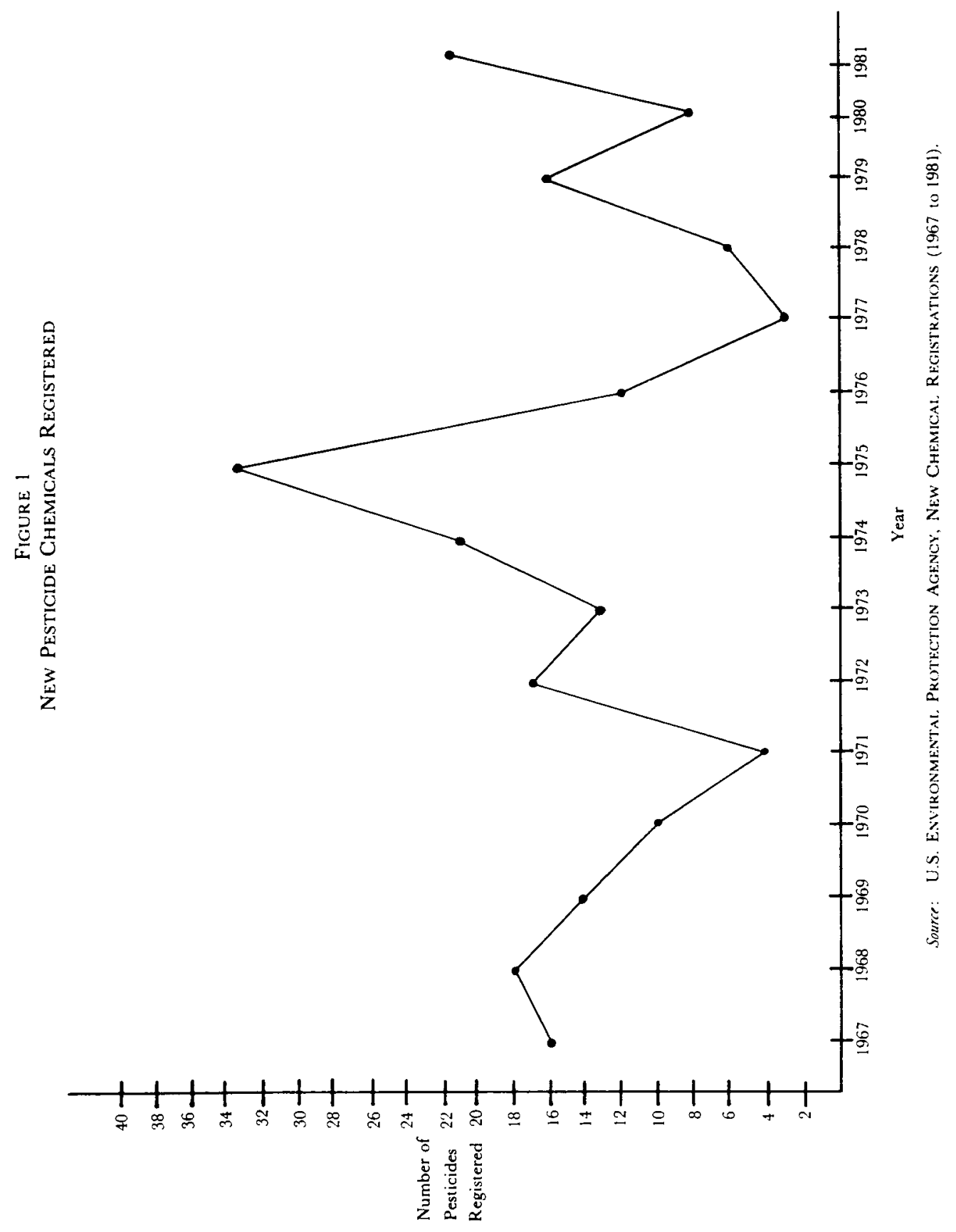


FIGURE 2

\section{Comparison of the Annual Approvals of New Drug \\ Molecular Entities Reflecting FDA's Value \\ Judgment of Therapeutic Potential}

Number of

New Molecular Entities

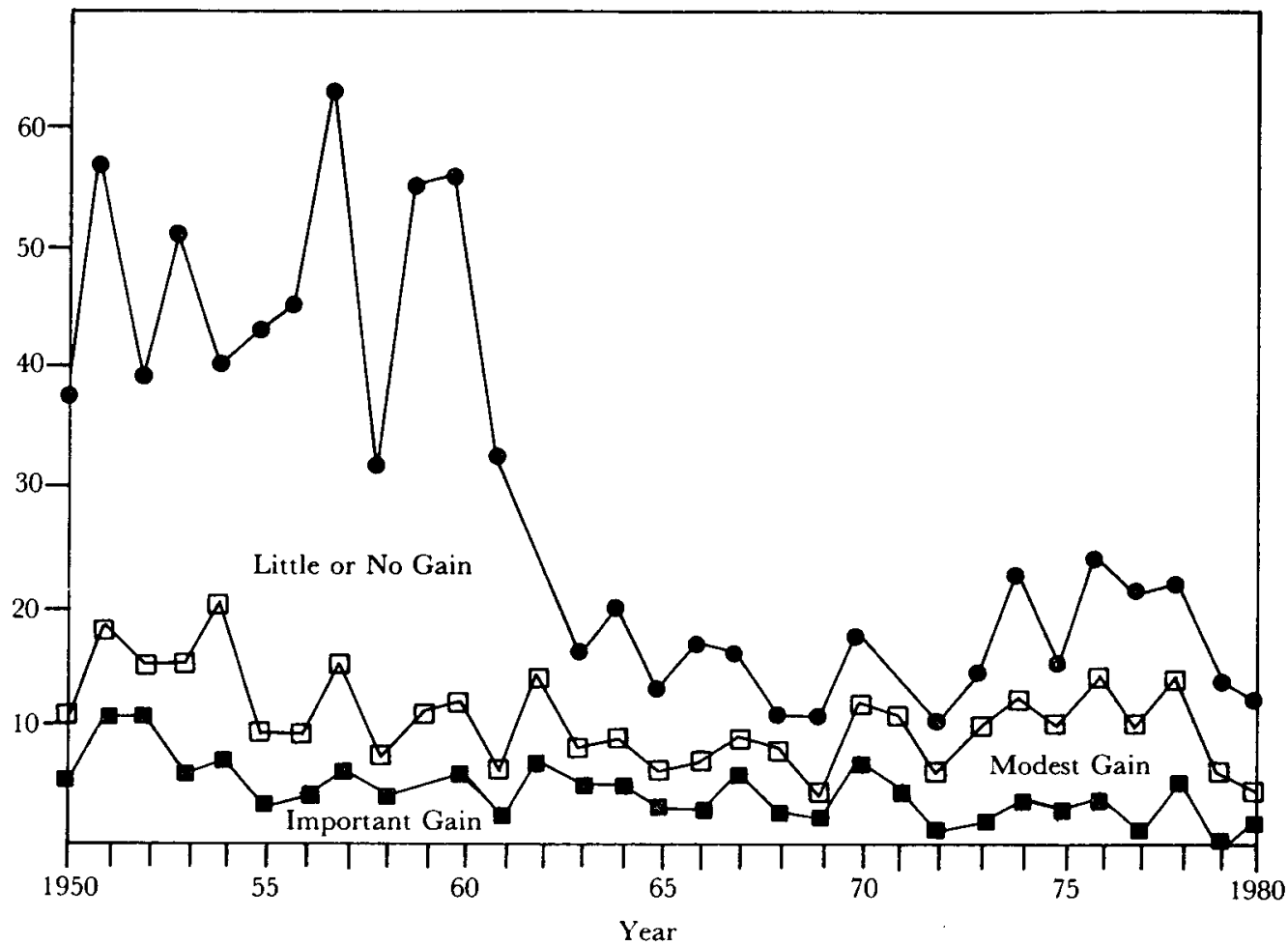

- Total Number of New Molecule Entities

日 $曰$ Sum of NCE's (new chemical entity) that are Important and Modest Gains

Number of Important Gains

Source: Office of Technology Assessment, Congress of the. United States, Patent-Term Extension and the Pharmaceutical. Industry 26 (1982).

slight decline in the average number of new pesticide chemicals registered since the late 1960's, but the pattern is erratic, and the largest number of registrations was in 1975 when the 1972 amendments to FIFRA ${ }^{34}$ were beginning to have their full impact. Similarly, the number of new pharmaceutical chemicals declined sharply in the early 1960's, but most of the decline was in drugs that represented little or no therapeutic gain. Mansfield found that in the chemical industry generally, the percentage of company-financed research and development expenditures devoted to projects aimed at entirely new products and processes declined from $37 \%$ in 1967 to $31 \%$ in $1980 .{ }^{35} \mathrm{He}$ also found that the percentage devoted to risky

34. 7 U.S.C. $\S 136$ (1982).

35. MANSFIELD, supra note 33. 
projects, those with a less than fifty-fifty estimated chance of success, declined from $37 \%$ in 1967 to $27 \%$ in $1980 .{ }^{36}$

TABLE 3

Ratio of Research \& Development Expenditures to Sales: Drugs, Pesticides, and Chemicals as a Whole

$\begin{array}{cccc}\frac{\text { Year }}{1965} & \begin{array}{c}\text { Ratio, } \\ \text { Drugs }^{\mathbf{a}}\end{array} & \begin{array}{c}\text { Ratio, } \\ \text { Pesticides }^{\mathbf{b}}\end{array} & \begin{array}{c}\text { Ratio, } \\ \text { Chemicals }^{\mathbf{c}}\end{array} \\ 1966 & 8.3 & & \\ 1967 & 8.6 & & 4.6 \\ 1968 & 8.7 & & 4.3 \\ 1969 & 8.5 & & \\ 1970 & 8.7 & & 3.6 \\ 1971 & 8.8 & & \\ 1972 & 8.6 & & \\ 1973 & 8.6 & 8.1 & \\ 1974 & 8.6 & 8.3 & \\ 1975 & 8.6 & 8.8 & \\ 1976 & 8.4 & 8.0 & \\ 1977 & 8.4 & 8.5 & \\ 1978 & 8.5 & & \\ 1979 & 8.2 & & \\ 1980 & & & \\ 1981 & & & \end{array}$

Sources: a. For drugs, Office of Technology Assessment, Congress of the United States, Patent-Term Extension and the Pharmaceutical Industry, 28 (1982).

b. For pesticides, National Agricultural Chemicals Ass'n, 1976-1981 Industry Prorile. STUDY (1977 to 1982). The NACA data on pesticides are highly variable because of year-to-year differences in the companies responding to the survey.

c. For chemicals, National Science Board, National Science foundation, Science INDICATORS 84 (1978).

Chemical industry research and development expenditures have generally increased over the past decade, even when inflation is taken into account. This is true not only for the industry as a whole, but also for its most intensely regulated sectors, drugs and pesticides (see Table 3). For both pesticides and drugs, research and development expenditures as a percentage of sales has remained constant at about $8 \%$, but there has been continuing real growth in sales. The result has been continuing real growth in research and development. It is undoubtedly true that a larger portion of this research and development is more "defensive" than it was ten or fifteen years ago, but there are no good data on the way the research and development expenditures are apportioned. Mansfield found that in the chemical industry the proportion of research and development expenditures going for basic research had declined in the last decade and that the proportion devoted to longterm (more than five years) projects had also declined. ${ }^{37}$ The ratio of industry

\footnotetext{
36. Id.

37. Id.
} 
research and development to sales for chemicals as a whole has also declined significantly.

\section{Product-Level Effects: The Commercialization Decision}

The analysis done by a firm to decide whether or not to commercialize a new product depends on the type of product line, the size of the firm, and the amount of investment necessary to bring the new product to market. A specialty chemical firm deciding to make fifty pounds of a new chemical may not do much more than a back-of-the-envelope calculation to determine the selling price. At the other extreme, a large firm may spend months analyzing alternative scenarios of cash flow, return on investment, etc., before deciding to proceed with a major new product.

The three elements that are crucial to any decision to commercialize are cost, time, and uncertainty. All three may be adversely affected by regulation.

The impact of regulation on direct costs depends on the nature of the regulatory requirement and on the type of firm or product impacted. Pollution control costs for industry as a whole amounted to $\$ 31.5$ billion in $1980 .^{38}$

These pollution control costs can adversely affect innovation in two ways. First, by using capital funds which might otherwise be invested in new plants or new equipment, pollution control investments may retard or prevent the introduction of process changes. Second, the costs of operating the pollution control equipment may reduce profits, which may in turn reduce the amount of money devoted to research and the development of new products.

Regulations directed at new products, such as the manufacturing notification requirements under $\mathrm{TSCA}^{39}$ or the pesticide registration requirements under FIFRA, ${ }^{40}$ increase the direct cost of marketing a new product. The increase in direct costs may result in a decision by a firm not to market a new product or even not to develop new products at all.

The average research and development cost for each new pesticide registered under FIFRA is estimated to be $\$ 6.9$ million. ${ }^{41}$ Of the $\$ 450$ million total pesticide industry research and development expenditures in $1981,67 \%$ was devoted to development of new products, $25 \%$ to product expansion, and $8 \%$ to reregistration and product defense. ${ }^{42}$ The average cost of filing a TSCA premanufacturing notification has been estimated to range from $\$ 5,000$ to $\$ 7,800 .{ }^{43}$

The impact of direct regulatory costs on product innovation is roughly proportional to the percentage that such costs bear to the total investment necessary to

38. Rutledge \& Trevathan, Pollution Abatement and Control Expenditures, 1972-80, SURvey OF CURRENT Business, Feb. 1982, at 50, 52-53 (published by the Bureau of Economic Analysis, U.S. Dep't of Commerce).

39. 15 U.S.C. $§ 2604$ (1982).

40. 7 U.S.C. $\$ 136$ (1982).

41. National Agricultural Chemical Ass'n, 1981 Industry Profile Study 7 (1982).

42. Id. at 9 .

43. E. Heiden \& A. Pittaway, Impact of the Toxic Substances Control Act on Innovation in the Chemical Specialties Manufacturers Industry, exhibit III-1 (1982) (prepared for Chemical Specialties Manufacturing Association). 
commercialize the product. For a large firm deciding whether to market a major new product, the direct regulatory costs are unlikely to significantly influence the decision. Data obtained from one large company on typical costs for developing a new pesticide indicate that added regulatory costs of $\$ 1$ million would not significantly influence the decision to market the pesticide. ${ }^{44}$ On the other hand, for a firm deciding whether to make a single small-volume batch of a new chemical, at a cost of maybe $\$ 10,000$ to $\$ 30,000$, almost any regulatory costs may influence the decision to proceed. The decision may hinge on the extent to which the costs can be passed on to the customer.

For major products involving large capital investments, time delay is likely to be a more important regulatory impact than direct costs. The same data on typical costs for a new pesticide cited above indicate that a two-year delay in registering the pesticide would reduce the cumulative net income from the product over its total commercial life by more than 50\%.45 The National Agricultural Chemicals Association (NACA) estimates that in 1981 the average time consumed from submission of a registration application for a new pesticide chemical to granting of a conditional registration was twenty-four months. ${ }^{46}$ On the average, more than seven years elapsed between initial discovery and conditional registration.

FIFRA and the Federal Food, Drug and Cosmetic Act are the only health safety statutes that impose significant time delays on new product development. The ninety-day waiting period for new chemicals under TSCA is not likely to be a major impediment to the devleopment of new chemicals except in the case of some small-volume chemicals needed rapidly for a particular customer's use. Smallvolume exemptions now being considered by the EPA probably would eliminate all cases when the TSCA time delay impeded innovation.

Uncertainty about what the regulatory requirements are, or will be, and whether regulatory action will be taken, is often cited by industry as the aspect of regulation that most impedes innovation. To a great extent the impact of uncertainty is psychological. It may lead corporate decisionmakers at all levels to be more cautious, to avoid radical innovations, and to resist putting large amounts of capital into development because liquidity is the best hedge against an uncertain future.

The impact of uncertainty may show up in more concrete ways than just affecting corporate psyches. The minimum acceptable return on investment may be adjusted for the degree of uncertainty, and thus a higher rate of return may be demanded from regulated products. For example, Rohm \& Haas calculates the minimum rate of return for a proposed new chemical at rates varying from $15 \%$ to $25 \%$, depending on the anticipated riskiness of the venture. ${ }^{47}$ Regulatory, technical, and marketing uncertainties contribute to riskiness.

44. This data was provided to the author on a confidential basis.

45. Id.

46. See National Agricultural Chemical Ass'n, supra note 41, at 7 .

47. Source for these figures is Dr. Sam Gusman, a coauthor of the CF-OTA Study, supra note 29. Dr. Gusman was an employee of Rohm \& Haas for 25 years, including positions as president of their pharmaceutical subsidiary and special assistant to the president of Rohm \& Haas. 
Whether uncertainty has a major effect on innovation is not really known. There is some evidence that, for example, commercial disposers of hazardous wastes have not installed new and improved methods of waste disposal because of the uncertainty over regulations to be issued by the EPA to implement the Resources Conservation and Recovery Act. ${ }^{48}$ On the other hand, at times when industry has been faced with a choice between uncertainty and potentially more stringent regulations, such as, for example, the testing requirements for new chemicals under TSCA, the industry has chosen uncertainty.

\section{Studies of TSCA Impact on Innovation}

The most recent focus of concern about the impact of regulation on innovation has been the effect of premanufacturing notification requirements under TSCA on the introduction of new chemicals. Four studies have attempted to determine this effect.

The first study, completed in December 1978, was done by Arthur D. Little, Inc. (ADL) for the EPA. ${ }^{49}$ The study was done quite rapidly under pressure from the EPA, and it is methodologically flawed to the point of being useless. The key data on the economic impact of TSCA is based on a nonrandom sample of seven chemicals. ${ }^{50}$ Ten chemicals are listed in the table, but two are the same chemical made by two different manufacturers, and two others are research and development chemicals excluded from TSCA. The problems with the ADL report were sufficiently great to be the subject of several days of Congressional hearings. ${ }^{51}$ The ADL study predicted that if TSCA notification costs were $\$ 10,000$ per chemical then the number of chemicals currently being commercially introduced would be reduced by $50 \%$. If notification costs were $\$ 40,000$ innovation would be reduced by $90 \% .{ }^{52}$

In response to the problems with the ADL study, the EPA commissioned ICF, Inc., another consulting firm, to do a similar study. The EPA issued the results in September 1980.53 The ICF study declined to predict the adverse impact of the premanufacturing notice requirements on innovation, noting that "[e]ven with all of the necessary data to measure the current rate [of new chemical introductions] and the likely reduction (data that industry has been reticent to provide), it is doubtful that the level of the reduction could be predicted ex ante. "54 The study estimated the direct costs of reporting a new chemical to range from $\$ 1,000$ to $\$ 9,000$, but stated that the direct cost "is the least important cost factor influencing chemical company decisionmaking . . . the uncertainties associated with possible EPA actions will generally outweigh the direct costs of complying with notice

48. 42 U.S.C. $§ 6901(1976)$.

49. Arthur D. Little, Inc., Impact of TSCA Proposed Premanufacturing Notification REQUIREMENTS (1978) (EPA document) [hereinafter cited as ADL Study].

50. Id. at III-12.

51. See Cost Benefit Analysis: The Potential for Confict of Interest: Hearings Before the Subcomm. on Oversight and Investigations of the House Comm. on Inlerstate and Foreign Commerce, 96th Cong. 2d Sess. (1980).

52. ADL STUDY, supra note 49 , at I-3.

53. ICF, Inc., Economic Impact analysis of Proposed Section 5 Notice Requirements, pts. $1-2$ (1980) (EPA document).

54. Id. at $\mathrm{x}$. 
requirements." 55

The ADL and ICF studies were followed by two related studies conducted by the Regulatory Research Service (RRS), one for the Chemical Manufacturers Association (CMA), 56 and the other for the Chemical Specialties Manufacturers Association (CSMA). ${ }^{57}$

The RRS studies attempted to show that the dire predictions made in the ADL study had in fact come to pass. The ADL study had estimated the number of new commercial chemicals introduced at 1,000 per year prior to 1979 when the TSCA premanufacturing notice requirements took effect. ${ }^{58}$ A 1976 study by Foster Snell estimated new chemical introductions at 2,200 per year. ${ }^{59}$ The RRS study for CMA took the annual figure for premanufacturing notices to be 470 , the number filed between July 1980 and February 1981. It then reduced this figure by the number of intermediate chemicals not sold to other manufacturers, and adjusted to account for premanufacturing notices on products still in the development stage, to arrive at an annual figure of 294 new chemicals per year, or a reduction in the number of new chemicals of $71-88 \% .60$

The RRS study for CSMA produced much milder results. For ingredient suppliers who were members of CSMA, new substance development on the average was $26 \%$ lower for 1979-1981 than it was for 1976-1978. ${ }^{61}$ Ninety-eight percent of this decline in innovation was attributable to smaller firms, those with sales under $\$ 100$ million. Product manufacturers (as contrasted with ingredient suppliers) within CSMA experienced no decline in the number of new chemicals manufactured.

The RRS studies have a number of limitations and shortcomings. First, there is no defensible way to arrive at a good estimate of the number of pre-TSCA new chemicals. Such an estimate involves making fine distinctions, for example, between research and development chemicals and test-market chemicals, which cannot accurately be made in retrospect. Second, many factors other than TSCA affect the rate of innovation. Third, the economic value of new chemicals not manufactured because of TSCA is likely to be less than the economic value of new chemicals that are manufactured.

The ADL and RRS predictions contrast with the actual rate of premaufacturing notice submissions, shown in Figure 3. The number of premanufacturing notices submitted has been increasing at a fairly steady rate. In the first half of 1982, 443 premanufacturing notices were submitted, a number equivalent to an annual rate quite close to ADL's estimate of the pre-TSCA rate.

\section{Figure 3}

It is likely that TSCA has had some adverse impact on innovation. Much of

55. Id. at $\mathrm{xi}$.

56. E. Heiden \& A. Pittaway, A Critique of the EPA "Economic Impact Analysis of Proposed Section 5 Notice Requirrements" (prepared for Chemical Manufacturers Association).

57. See E. Heiden \& A. Pittaway, supra note 43

58. ADL STUDY, supra note 49 , at I-3.

59. See Foster D. Snell, Inc., supra note 23.

60. See E. Heiden \& A. Pittaway, supra note 56, at 56 .

61. See E. Heiden \& A. Pittaway, supra note 43 , executive summary at 1-2. 
this adverse impact is probably due to misconceptions about the premanufacturing notice requirements rather than the actual costs of submitting a premanufacturing notice, which are generally insignificant. Many small manufacturers have the misperception that toxicological data must be submitted with a premanufacturing notice, and some industry spokesmen have even encouraged

Figure 3

Premanufacturing Notices

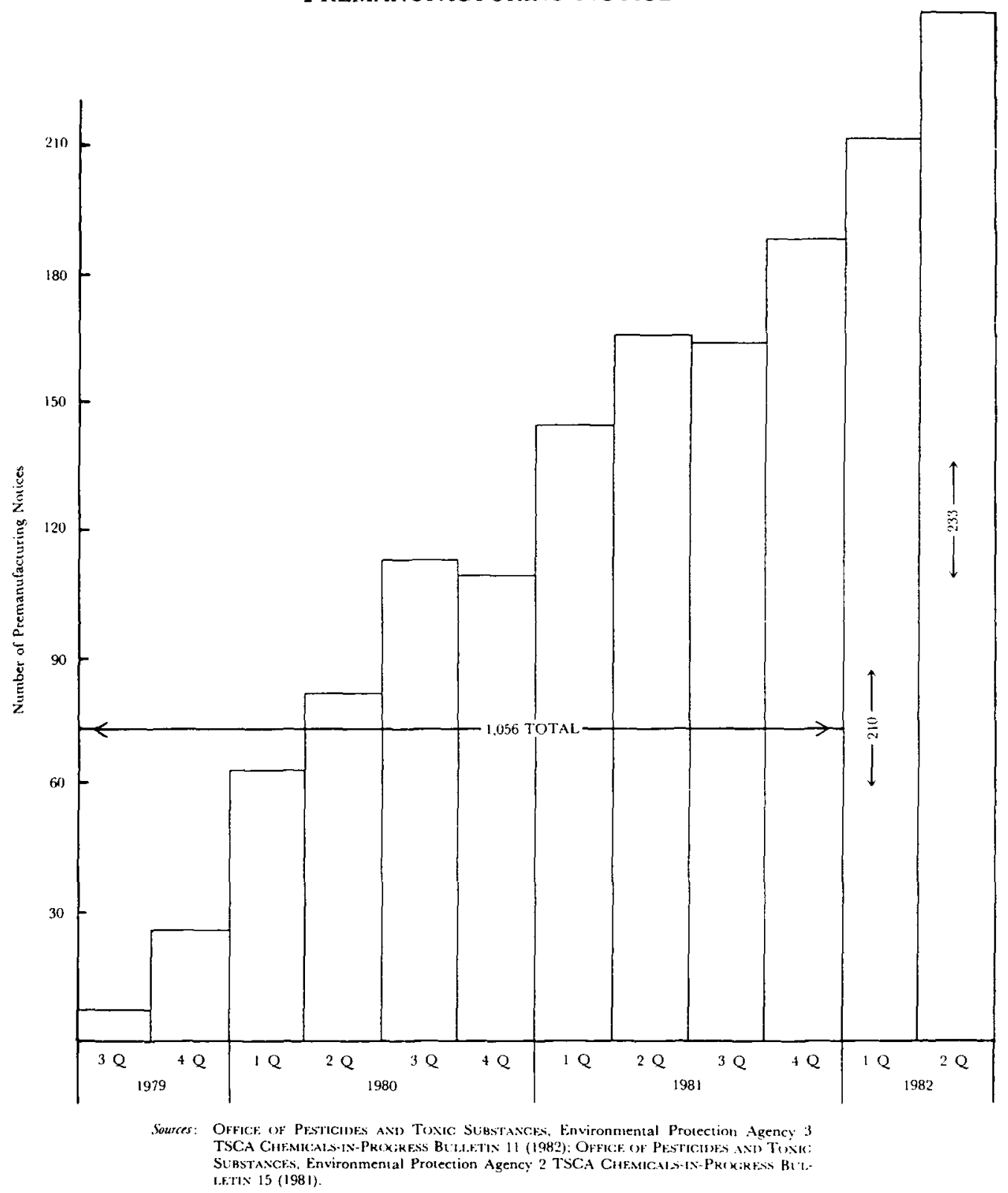


them in this mistake. ${ }^{62}$

\section{III}

\section{Favorable EfFects of Regulation on InNOVATION}

Although the negative effects of regulation on innovation have received the most attention, there are major favorable effects as well. The most obvious favorable effect is the shift in corporate strategies and procedures so that new products and new plants are safer and healthier. Pollution control at new plants and toxicological testing of new products are now important considerations which have been institutionalized in the structure of most major corporations. The effect may not be to increase the number or dollar value of new products or processes, but the quality of innovations has been changed and the decisionmaking processes leading to innovations also have been changed.

\section{A. Process Innovations}

Pollution control and other environmental or health regulations have stimulated the development and adoption of a number of innovative production processes. For example, a number of electrolytic caustic soda-chlorine plants have converted from using mercury cells to diaphragm cells, and from using graphite anodes to dimensionally stable anodes. Although costly, these changes have substantially reduced pollution problems and control costs and have increased plant efficiency within the industry. The new processes have helped domestic producers remain competitive with foreign producers and have reduced pressures for manufacturers to relocate abroad. ${ }^{63}$

Many industries have found that the cost of complying with new regulations can be reduced through reclaiming and recycling material that previously was discharged into the air or water. The electroplating industry, for example, was expected to be one of the industries hit hardest by regulations covering toxic water effluents. Since the industry consisted primarily of small, local operations and, at the same time, was the largest contributor of toxic metal wastes into public sewage treatment plants, the EPA estimated that up to $20 \%$ of all electroplating firms would be forced out of business by the water regulations. This has not happened because technological advances, both in production processes and recycling techniques, have enabled many electroplaters to reduce their discharges of toxic wastes. This has not only reduced the toxic waste problem but has also led to major cost savings through the recycling of expensive metals. ${ }^{64}$

Many chemical firms have introduced process changes in response to environmental regulations. A number of these changes have led to more efficient production. However, it should not be implied that firms typically save money by complying with pollution control regulations.

62. See, e.g., Address by J.R. Yost, Effects of TSCA on Small Chemical Companies, American Chemical Society in Las Vegas, Nev., (Mar. 31, 1982).

63. H.J. Leonard, Environmental Regulations and U.S. Industrial Strength 165 (Tent. Draft July 1983) (forthcoming publication).

64. Id. at 167-68. 


\section{B. Product Innovations}

Regulations can also result in product innovations. This innovation can happen in three ways. First, new markets may be opened because regulatory action removes existing products from the market or threatens to do so. The banning of DDT and the likelihood that other chlorinated hydrocarbon pesticides would be removed from the market encouraged the development and commercialization of alternative kinds of pesticides. Proposed regulations to limit the uses of asbestos have led to a search for alternative materials.

Second, apart from any direct regulatory action or threat, the existence of health and safety regulatory mechanisms may encourage companies to develop and market products whose commercial superiority rests in part on their being less hazardous for humans and the environment. The development of so-called biorational pesticides is an example.

Third, regulation can encourage the development of products necessary for implementing regulatory action. A wide variety of new pollution control products has been developed over the past fifteen years. Also, a number of devices for monitoring and analyzing chemicals have been invented and marketed because of the demand created by regulations.

\section{IV}

\section{Striking a Balance}

Although regulation may have stimulated the development of some new products or processes, it is clear that health and safety regulation must be justified on the grounds of improved health and safety, not as an obscure and indirect way of stimulating innovation. How does one strike a balance between greater health protection and more innovation? Unfortunately, it cannot be done through costbenefit analysis.

For almost all health and safety regulations the benefits in greater health protection are not known even within an order of magnitude. The costs of innovation are even less quantifiable. This article has reviewed some of the problems of determining whether and to what extent innovation has been reduced by various regulations. But even if one knew exactly how many new chemicals were not produced because of TSCA regulations, one would not be able to express the cost in dollar figures. Such a calculation would require knowing the consumer's surplus and the producer's surplus of the chemicals not produced and subtracting from the sum of these two figures the sum of the consumer's and producer's surpluses of the existing chemicals that would have been replaced by the new chemicals. No one has even made, or is likely to make, the crudest estimates regarding any of these numbers.

In the absence of any good analytical methodology for balancing health benefits and economic costs, personal and institutional values will play a crucial role in any decisions that are made. In fact it is probably a waste of time to try to pass some overall judgment about the benefits and costs of health and safety regulation. If one accepts the basic premise that some regulation of chemicals is socially desir- 
able then the more relevant question is how the existing regulatory framework can be changed so that its benefits are increased and its costs reduced.

The exploration of how the regulatory framework can be improved is a discussion that is beyond the scope of this article. It needs to follow three broad paths. First, the statutes themselves should be examined for ways to make the legislative framework of regulation simpler and more efficient. If the debate over the Clean Air Act is any example, such an examination is not likely to happen in a constructive way in the near future. Second, new ways of implementing the statutes through innovative approaches such as regulatory negotiation, market mechanisms, and better intergovernmental relations must be developed and tried. Third, and probably most important, the quality of the civil service and of the administration of the federal government must be improved. Any regulatory scheme can be undermined by administrators who are poorly qualified for their jobs or by good people who are forced to work under impossible constraints. The current administration is simply the latest and most extreme force in a decade-long effort to obstruct, denigrate, and paralyze the federal civil service. The so-called regulatory reform legislation which came close to passage in the last session of Congress would strike another blow in this direction. It will "reform" regulation by making it more time-consuming and cumbersome and by making the regulatory process still more byzantine and inflexible. The time has come to try to restore the integrity and efficiency of government service. Such a restoration would be a crucial step in improving the effectiveness and efficiency of regulation and in reducing any adverse effects on innovation. 